\section{Graduate students galore}

\section{The government document on British graduate education fails to grasp conspicuous nettles.}

The poor, it is said, are always with us. So too are graduate students, called postgraduate students in the United Kingdom. And the analogy with the poor is not misplaced. One of the strongest threads running through the report of the working party on postgraduate education in Britain set up by the Advisory Board for the Research Councils in 1979 and published last week is the evidence it provides for the impoverishment of graduate students while following their courses and the poor financial prospects which await them afterwards. This is one reason why any thorough study of the arrangements for organizing and supporting postgraduate students must also ask whether the whole enterprise is worthwhile. This study*, which bears the unmistakable stamp of its chairman Sir Peter Swinnerton-Dyer, has done this and more. While concluding that graduate students (a comparatively recent innovation in British universities) have come to stay, the working party has also provided a view of the working of the British system of higher education that could not otherwise have been obtained.

Part of the troub!e with graduate education is that it does not fit in easily with the rules that the administrators of higher education have developed for deciding how much money should be spent on supporting universities. So much is evident from the length of time taken after first graduation for different students to qualify for a $\mathrm{PhD}$ or some equivalent research degree. Why should some students take only two years, and others five or more? What, in any case, is signified by a $\mathrm{PhD}$ degree? Does it denote competence in research, or extra knowledge in some special field or is it merely a sign that its usually proud possessor has qualified by earlier performance for financial support or has been sought after as a research assistant by some supervisor looking for help with his own research? Because circumstances may make each of these readings valid, it is natural that administrators should be at a loss to know how much public support should be devoted to graduate education. These are some of the perplexing questions that seem to have prompted this working-party's study.

So far as they go, the recommendations of the working party are sensible enough. Yes indeed, it says, the time has come for the British government to give up the attempt that its predecessors have made ever since the Second World War to justify spending on university research by means of some calculation that there is a direct link between research expenditure and the improvement of national prosperity. Moreover, the argument goes, it is also impossible, or at least impracticable, to relate public expenditure on the support of graduate students to the needs of employers in different fields. For what employers consider to be their needs are moving targets. The only substantial exception to this chastening truth, the report concludes, is that there may be a continuing need for short-term graduate courses in fields such as computer science or toxicology, where shortages of skilled manpower have recently become apparent - and where they may nevertheless disappear without reason any time. So, the argument goes, the research councils should be quicker off the mark both in their willingness to support courses such as these, if necessary at universities chosin centrally - and then more ready than they are at present to close them down. Nobody will dissent from these conclusions. How readily will the research councils adopt them?

In at least one important respect, however, it is unfortunate that the working party has not gone further. As things are, the chief source of support for graduate students at British universities are the research studentships handed out each year by the research councils. The chief recipients of these grants are not, however, students but the departments which eventually house them and which are, within the rules, then empowered to select the students they consider to be best qualified for a career in research. The working party recommends that the research councils should be more vigilant than in the past in matching the quotas to the reputations of their dependent departments in research - and that departments whose students seem to take too long to qualify for their degrees should be penalized. The snag is that in present circumstances, the principle of the quota system needs radical re-examination. When the whole pattern of British higher education is being changed in such a way that some university departments will become centres of excellence and others in the same field will have virtually to abandon hope of ever being strong in research, is it equitable or even wise that the appointment of state-subsidized graduate students should be left entirely to the lucky (and no doubt deserving) university departments? Should there not at least be some device for making sure that promising people from less favoured universities have a chance?

The working party might also have profitably gone further in its examination of the character and quality of graduate education in British universities. It seems to have been mesmerized by the publicity given in recent years to the sharp difference between the tenor of PhD courses in the natural and the social sciences. In the natural sciences, it seems to be accepted that in three years or thereabouts, a person can pick up a sense of how to conduct research and also to carry out a substantial piece of work, but that in the social sciences it takes three years to acquire "research training". So, the working party argues, the social science departments of the United Kingdom should tailor their graduate courses to the acquisition of research skills; whether or not successful students are then given a $\mathrm{PhD}$ degree becomes irrelevant. But how does it arise that in the United States and elsewhere, the normal pattern of graduate courses in the natural sciences includes a more substantial element of research training ("taught courses" and all that) and often a longer time in harness? Has the committee plumped for three years as the normal period of graduate education leading to a $\mathrm{PhD}$ out of deference to the British Government's wish to economize where it can, and without sufficient regard for the quality of graduate education?

The economic value to students of graduate education in British circumstances is exceedingly problematical. Starting salaries for $\mathrm{PhD}$ graduates tend to be lower than those of people who find jobs immediately after their first degree, no doubt because substantial proportions of $\mathrm{PhD}$ graduates choose to take jobs in academic life. The working party's survey of employment among British graduates of various kinds does not pretend to throw light on economic prospects in the longer term, which is entirely forgivable. But the data that it has uncovered are sufficient to give the lie to the now common supposition in Britain that graduate education is an extravagant luxury, a way in which perpetual students may forsend the harsh realities of the real world for a few years - and often at the public expense. So the working party is right to flirt with the notion that the public stipends of chosen graduate students should be linked not with the grants paid to publicly-supported undergraduates but with those of research assistants doing real jobs in a laboratory environment.

Fine tuning such as this will help to make the present system function more efficiently, but will not by itself revivify graduate education in British universities. Traditionally, $\mathrm{PhD}$ courses have been devices for selecting future academics but, when universities are shedding staff, there are many fewer opportunities than aspirants. Is it then surprising that many graduate students become dispirited, and give up along the way? So the most urgent need is that universities should acknowledge that even the most talented graduate students will need to find other than academic jobs. Industrially related graduate courses, such as those sponsored by the Science and Engineering Research Council are valuable but will not suit every need. So should not universities pay more attention to the fate (as well as the selection) of their graduate students? And should not more of them acknowledge that there is a crying need for more than one-year graduate courses designed deliberately to round off the standard three-year first degree course by the acquisition of some employable skill?

*Report of the Working Party on Postgraduate Education, Cmnd. 8537, HMSO, $£ 7.00$ 